\title{
Industrialization and Bursa, the Evolving City: Changes in Housing Character after 1960
}

\author{
Saliha Tupal Yeke, Selen Durak, and Tulin Vural Arslan
}

\begin{abstract}
Social identity of Bursa develops in line with the changes in its population and social, economic and political structure. The establishment of Turkey's first planned organized industrial district in Bursa in 1962 was a breaking point for the social and economic life. This process played an important role in the formation of new residential areas and new housing typologies in the city, as well. Models of traditional Turkish house fell into disuse and construction of apartment blocks and mass housing started to be seen within the framework of modernization. This study aims to discuss the changes in housing character of Bursa in terms of plan typologies. These changes are discussed by means of evaluating the plans of housing units which can be seen as the significant examples of different periods since 1960s.
\end{abstract}

Index Terms-Bursa, effects of economic development on architecture, urban development, housing character after 1960.

\section{INTRODUCTION}

Economic developments, which started approximately seven centuries ago, played a very important role in shaping social and spatial structure of Bursa (see Fig. 1), which has a significant historical background [1]. The city was limited to the area surrounded by city walls prior to its conquest by the Ottomans. After Orhan Gazi conquered Bursa, he left the walled city as it was with its palace, houses and bazaar and expanded the city beyond its walls making room for new Turkic tribes coming from Anatolia. As a result, cultural and economic structures were established outside the city walls. Ottoman khans (Ottoman Turkish buildings that combined an urban inn, stable, storage depot and wholesale selling point) and covered bazaars founded in the city by the Sultans show that Bursa was a commercial center with an increasing importance in the early periods of the Ottoman Empire [2]. Many economic developments were witnessed in the $15^{\text {th }}$ and $16^{\text {th }}$ century in Bursa, whereas commercial life stagnated in the $17^{\text {th }}$ and $18^{\text {th }}$ centuries [3].

Economic developments in Bursa continued after the foundation of the Republic of Turkey in the early $20^{\text {th }}$ century, as well. Ipekis Bursa Weaving Factory, Sumerbank Merinos Wool Woven Fabric Factory and Gemlik Artificial Silk Factory were opened in Bursa in this period. Industrialization caused population to migrate from rural areas to urban areas. 40.000 tractors, which were brought to Turkey in 1950s as a

Manuscript received December 31, 2014; revised May 4, 2015.

S. Tupal Yeke is with Sama İnşaat, Baglarbaşı M. 3.Elif St. Nr: 20 Osmangazi, Bursa, 16160, Turkey (e-mail: saliha.tupal@gmail.com).

S. Durak and T. Vural Arslan are with Uludag University, Faculty of Architecture, Gorukle Kampusu, Nilufer, Bursa 16059, Turkey (e-mail: selendurak@gmail.com, tulinv@yahoo.com). part of the Marshall Plan by the United States of America resulted in a surplus of labour force. This surplus, then, migrated to cities to find jobs. An increase in population was observed in Bursa like in all other big cities after 1950s [4].

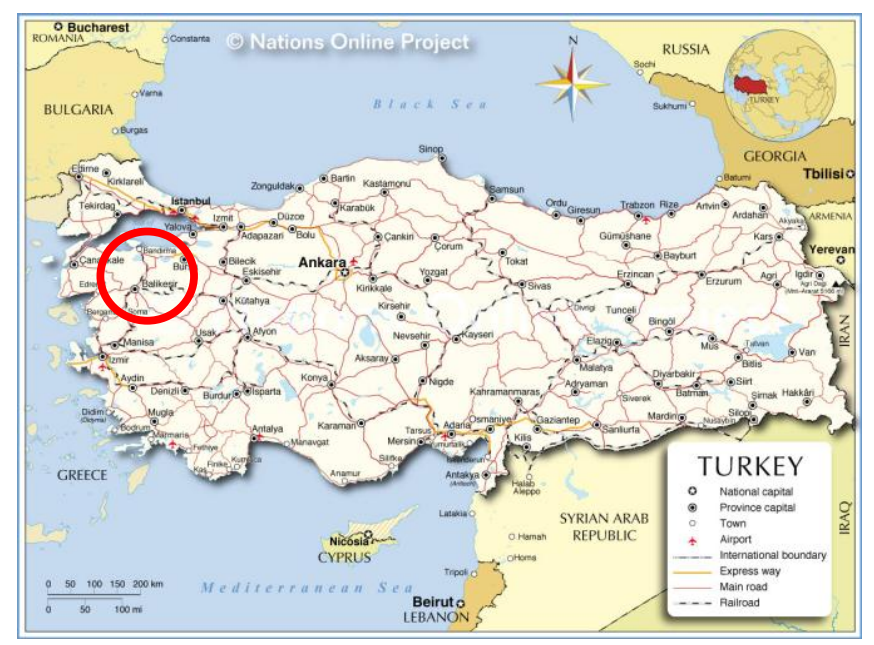

Fig. 1. Map of Turkey and location of Bursa.

http://www.nationsonline.org/oneworld/map/turkey-map.htm

The increase in population correlated with the economic development and Bursa attracted regional labour force and capital. Leading companies of the automotive industry entered into Bursa, which changed the social and economic structure. Urban development increasing after 1960 resulted in different income groups' residing at different locations. Although the city became an industrial center, the city center could not become a trade and finance center [5].

Bursa Organized Industrial Zone contributed significantly to the increasing power of the economy of the city Fig. 2. Being the first and pilot zone in Turkey, Bursa Organized Industrial Zone is of great value to the regional and national economy [6]. Organized industrial zones were first seen in the United States of America. The aim was to help private companies to make profit in special zones by providing them with industrial lands with infrastructure. The first organized zone was founded in Bursa in 1962 with the credit given by the World Bank [7]. In line with the developing economy, new industrial zones were established to meet the demand. Today, there are fourteen industrial zones in Bursa.

Raw material production and Bursa's function as a point of intersection between important residential areas in the hinterland of the region played an active role in attracting important economic investments in Bursa. There are two hundred and fifty factories in Bursa including industrial zones. Social life has changed in parallel with the economic conditions [8]. 


\section{HOUSING CHARACTER IN BURSA AFTER 1960}

Following the establishment of the Organized Industrial Zone in 1962, the individuals who would meet the demand in labor force and make use of the new opportunities preferred living in the city. As a result, rate of rural-urban migration increased and Bursa's population, which was around 70.000 between 1939-1951 increased to 120.000 between 1968-1992. According to the data of the Turkish Statistical Institute (TUIK: Turkish Statistical Institute), Bursa's population reached up to 2.787 .539 in 2014 .

\section{Changes And Developments ObSeRVed In Housing PRODUCTION PROCESSES}

Main factors for increase in demand for housing are income and demand flexibility, housing prices, user preferences, housing production and production technologies [9]. Housing production technologies evolved in time in line with industrial technological developments and became an important indicator for housing preferences. The increase in the population of Bursa caused by industrial development after 1960 resulted with an increase in housing needs. In this regard, many contractors coming to Bursa from other cities started to construct individual apartment blocks on vacant lands or on the lands of tradition houses, which could be found in small numbers in the city center. However, the city center could not meet the increasing housing need caused by increasing population, thus new residential areas were formed around the city center. Development of Cekirge and Kukurtlu districts (see Fig. 2), which were preferred by high-income group, are significant examples for these new areas.

There have been changes in housing production process since the end of 1980s. Large scaled housing complexes constructed by housing cooperatives replaced the houses constructed by contractors with a small capital.

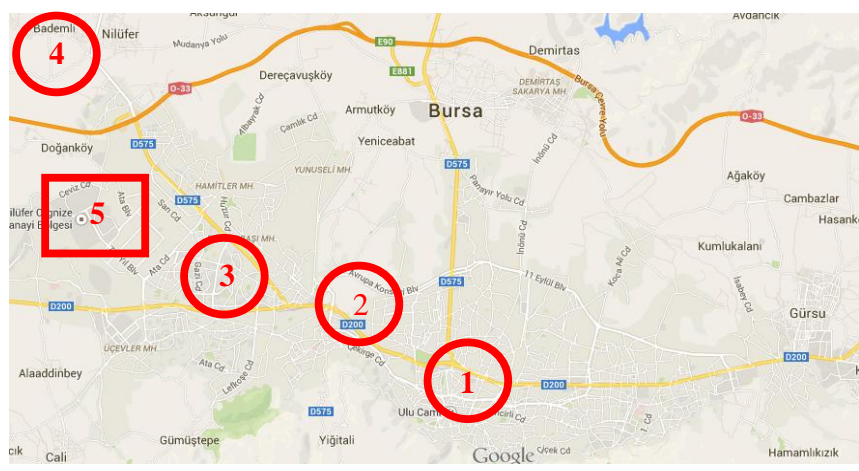

Fig. 2. The main roads, districts and city center of Bursa: 1) City center, Nalbantoglu district, 2) Kukurtlu, Cekirge district, 3) Nilufer, Fethiye, İhsaniye, Besevler district, 4) Bademli district, 5) Bursa organized Indus. trial zone.

Increase in cooperative housing occurred at the same time with the developments of the urban areas towards the west direction of the city. Multi-storey apartment block complexes constructed in villages like Ihsaniye, Fethiye and Besevler became popular among middle and high income groups Fig. 2. Thanks to housing complexes constructed in Gorukle District, the western end of the city, for Turkish immigrants coming from Bulgaria back to Turkey in 1989, small scaled residential areas between Gorukle and İhsaniye gained a new identity and turned into satellite cities.

While these new housing complexes met the expectations of the middle-income group, the high-income group, which emerged as a result of economic developments, preferred to live in villas with garden, pool, walking trails, security guards, that appeared in the northwest side of the city, in other words, in villages like Bademli and Niluferkoy between Mudanya and the city center Fig. 2.

Especially in 2000s, when the concept of neighborhood could only be seen in the city center, this new character with housing complexes, café-restaurant, entertainment venues and shopping centers became very popular due to the changes in transportation network. The new housing complexes were more protected and met not only housing needs but also many other social demands. Increasing demands caused many construction companies to start production in Bursa. Since there are not many vacant lands inside the city center, this new housing character spread to the lands on both sides of the important highways passing through the city.

\section{Changes in Urban Space And Individuals' Housing PREFERENCES}

In 1980s, people started to lead their lives at the periphery of the cities depending on industrialization, population increase, dense traffic, noise and air population. However, this alternative life style was not just caused by the necessities of the time but it also became a trend to have a post-modern life style among high-income groups. Gated housing complexes first started to be seen in Istanbul, where urbanization problems and global processes were first experienced, and then in other big cities exposed to migration.

Due to its physical and socio-economic proximity to Istanbul, Bursa was affected by the developments and become one of the first cities, where gated housing complexes were constructed. Gated communities composed of apartment blocks, complexes, many social activity spaces and commercial centers started to appear in the city [9].

As a result of this process, construction works have been intensified on vacant fields, transportation network have been extended to the new residential areas, and suburbanization accelerated on the western side of the city. Multi-storey apartment blocks in housing complexes were started to be produced. These houses were not designed only to meet the housing need of an individual but they also served as social facilities, where individuals could spend their daily lives [10].

\section{Plan TyPes SHAPING HOUSING CHARACTER}

In this part, housing examples, built in different time periods, have been explained in order to understand the changes in housing typology, and spatial planning. These changes have been elaborated on under the following five classifications:

1) Apartment blocks constructed by contractors replacing 
traditional houses in the city center (Nalbantoglu, Maksem, Setbaşı, etc.)

In traditional housing typology, there is a hall in the center and all the other spaces in the house open to this hall. The plan of the apartment built in Osmangazi District that was constructed in 1960s includes a hall with a living room, a kitchen, a bathroom and WC around. This example has an area of usage with $100 \mathrm{~m}^{2}$ (see Fig. 3).

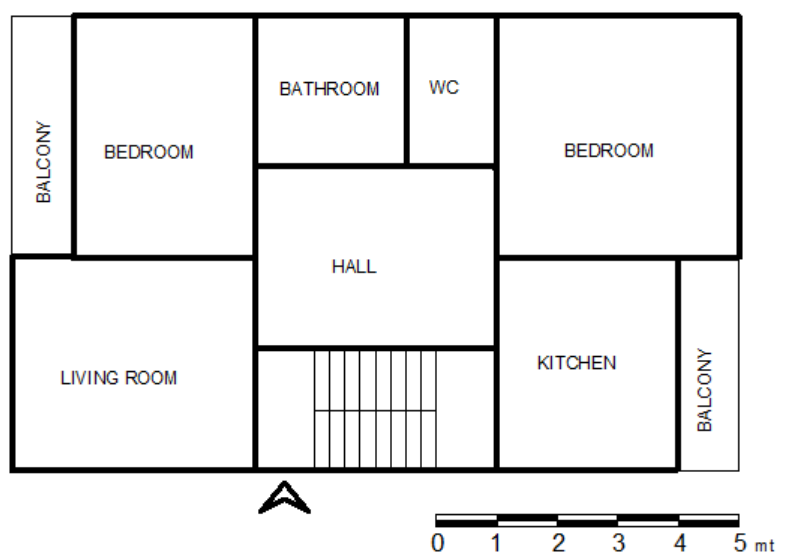

Fig. 3. The plan of an apartment built in Osmangazi District in 1960s.

Common hall in the center, which was one of the key features of traditional house plans was replaced by narrow corridors later. The demand for more rooms increased in time. In apartments with one or more balconies, built-in barbecues were added as an extra facility. Saloons, which were used as a guest room and opened only when a guest visited, started to be used as living rooms in daily life. The other rooms were used as bedrooms for parents and children.

2) Apartment blocks constructed by contractor on vacant

lands close to the city center (Çekirge, Kukurtlu, Altıparmak, etc.)

As can be seen in the plan of an apartment in Kukurtlu, there are two rooms, a living room and a common bathroom. This example has an area of usage with $120 \mathrm{~m}^{2}$. Instead of traditional sofa plan, long corridors start to bind the rooms together (see Fig. 4).

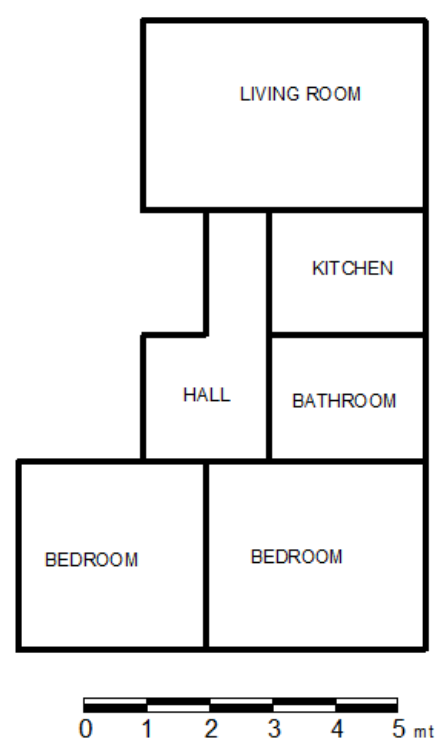

Fig. 4. The plan of an apartment built in Kukurtlu District in 1980s.
3) Housing complex construction by housing cooperatives on the urban fringe (Ihsaniye, Besevler, etc.)

In buildings constructed in Nilufer District in 2000s, several balconies were common and en-suite bathtroom was added to bedrooms. Number of rooms was increased to three and narrow corridors where rooms are opened were transformed into a large hall at the entrance. The first examples built in this region, that were built by the housing cooperatives were simpler. They used average quality materials, and in most of the buildings they used same plan schemes, including narrow balconies, small rooms, small halls, a bathroom and a toilet (see Fig. 5-Fig. 7).

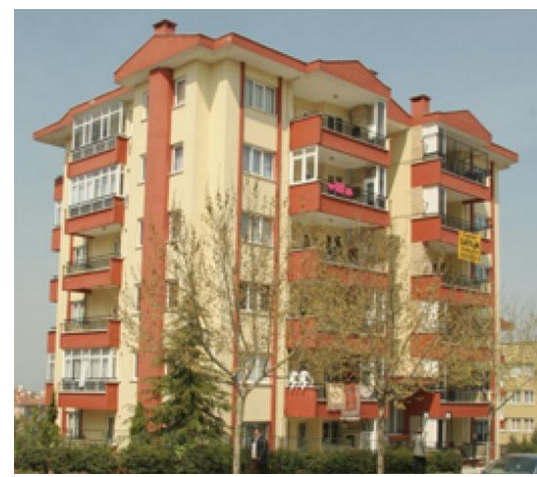

Fig. 5. Photo obtained from www.samainşaat.com by the courtesy of Mr. Mahmut Sabuncuoglu.

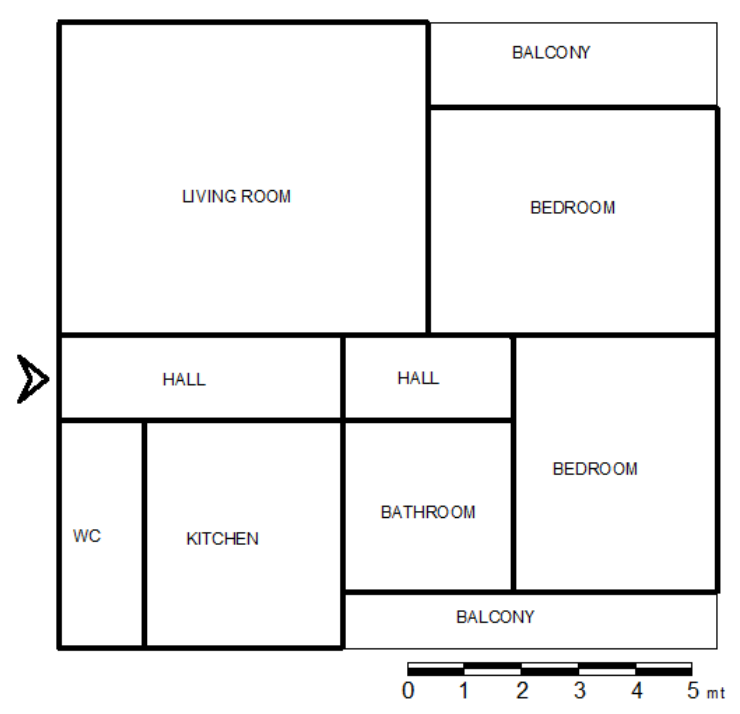

Fig. 6. The plan of an apartment built in Nilufer District in 1980s.

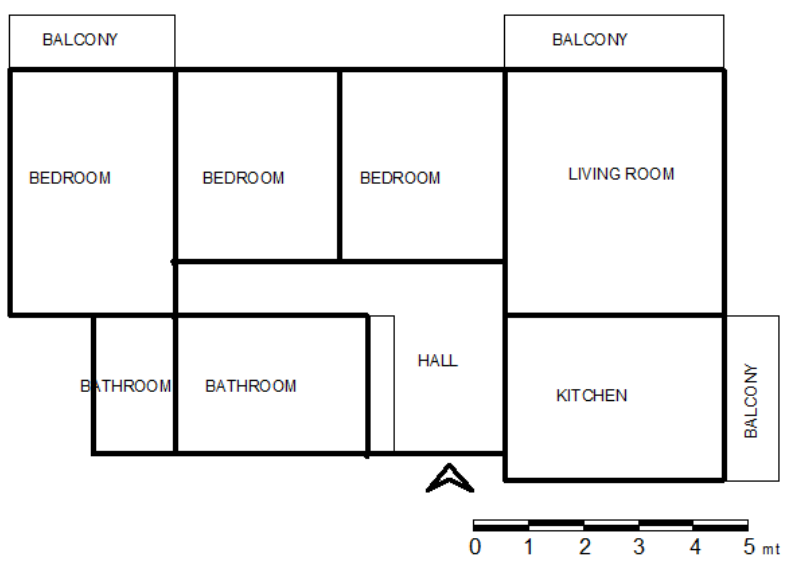

Fig. 7. The plan of an apartment built in Nilifer District in 2000s. 
Nowadays, we see housing examples with balconies having almost the same dimensions with the rooms and additional spaces like storage room and laundry room (see Fig. 8 and Fig. 9).

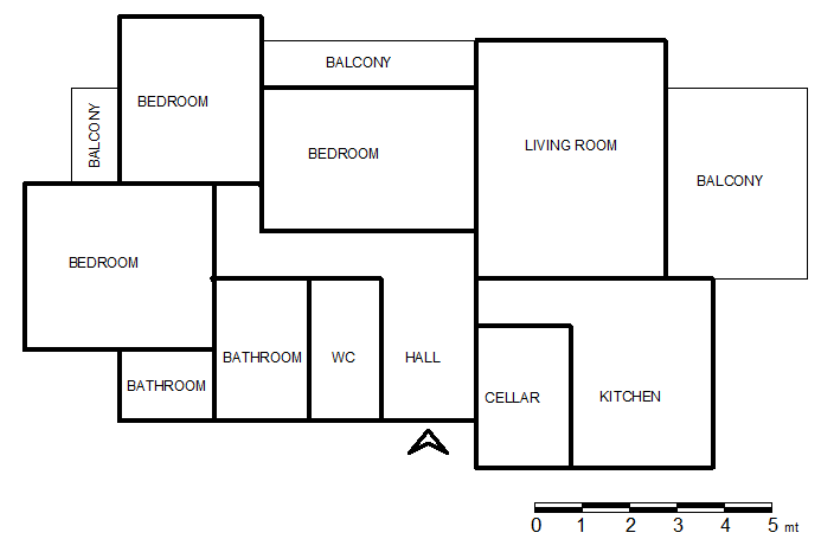

Fig. 8. The plan of an apartment built in Nilifer District in 2000s.

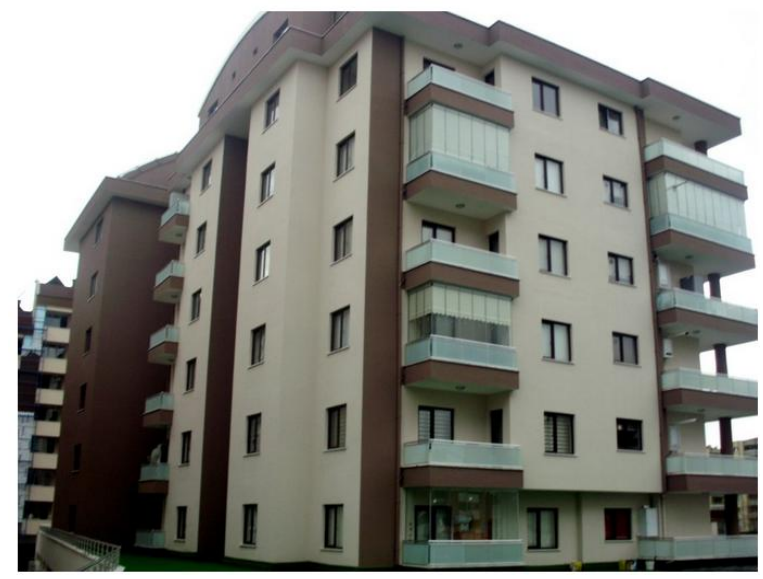

Fig. 9. Photo obtained from www.samainşaat.com by the courtesy of Mr. Mahmut Sabuncuoglu.

4) Low-rise housing with gardens constructed by contractors on the periphery of the city (Bademli District)

As can be seen in the plan of the house found in Cesa Housing Complex in Bademli District, there are three floors including a Turkish hamam or sauna. There is a kitchen on the bottom floor; a living room, WC and another kitchen on the ground floor; three bedrooms, one common bathroom and one en-suite bathroom on the top floor. This example has an area of usage with $400 \mathrm{~m}^{2}$ (see Fig. 10-Fig. 14).

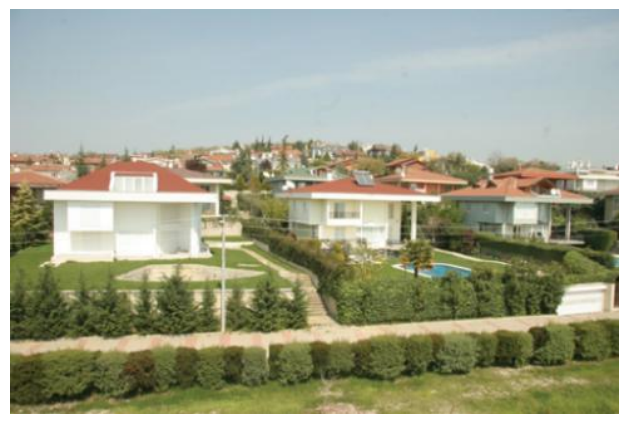

Fig. 10. Photo obtained from www.samainşaat.com by the courtesy of Mr. Mahmut Sabuncuoglu.

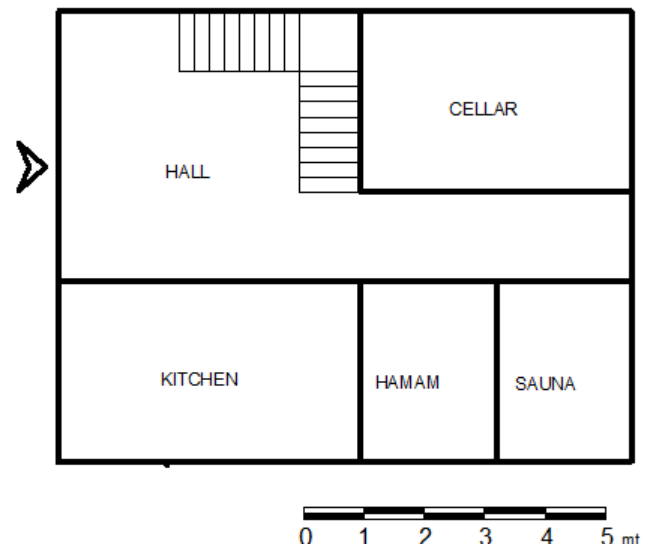

Fig. 11. The ground floor plan of a villa built in Bademli in 1990s.

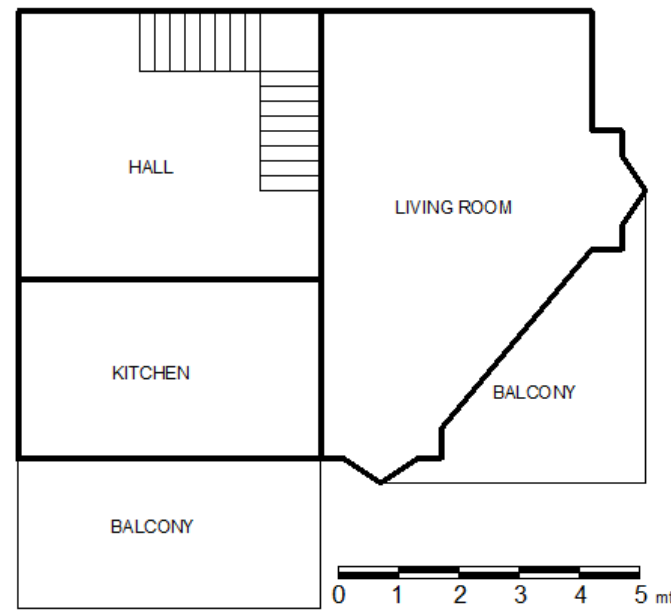

Fig. 12. The first floor plan of a villa built in Bademli in 1990s.

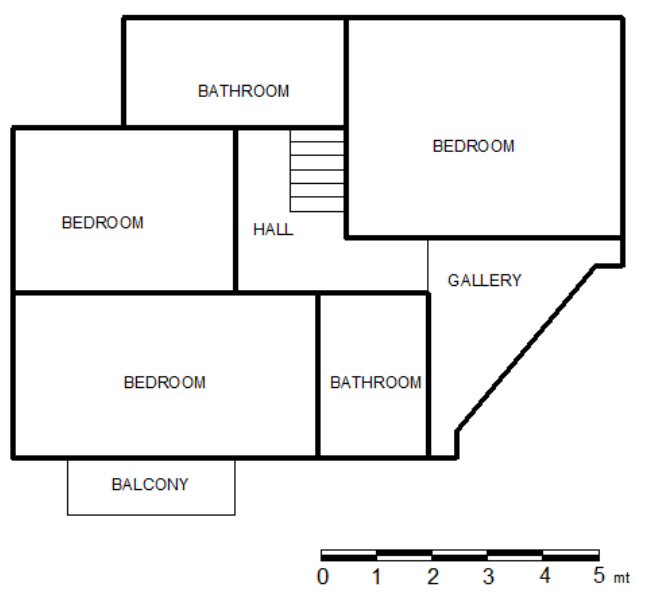

Fig. 13. The second floor plan of a villa built in Bademli in 1990s.

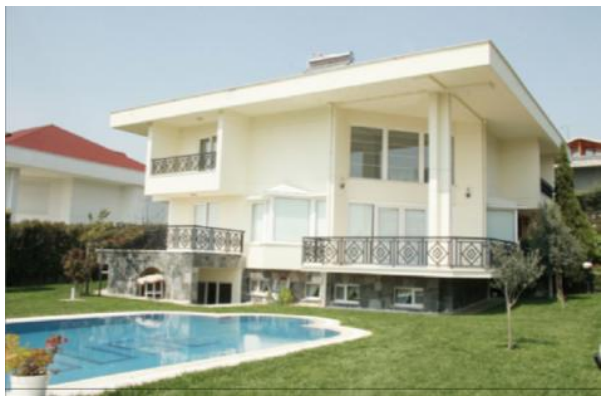

Fig. 14. Photo obtained from www.samainşaat.com by the courtesy of Mr. Mahmut Sabuncuoglu. 
5) Gated housing complexes constructed by large scaled construction companies on the periphery of the city (Korupark, Harmony Towers, Misia, etc.)

The apartment in Korupark Housing Complex has four rooms, a living room, one common bathroom, one en-suite bathroom, WC, a laundry room and two balconies. Total area of usage in this apartment is $240 \mathrm{~m}^{2}$ (see Fig. 15).

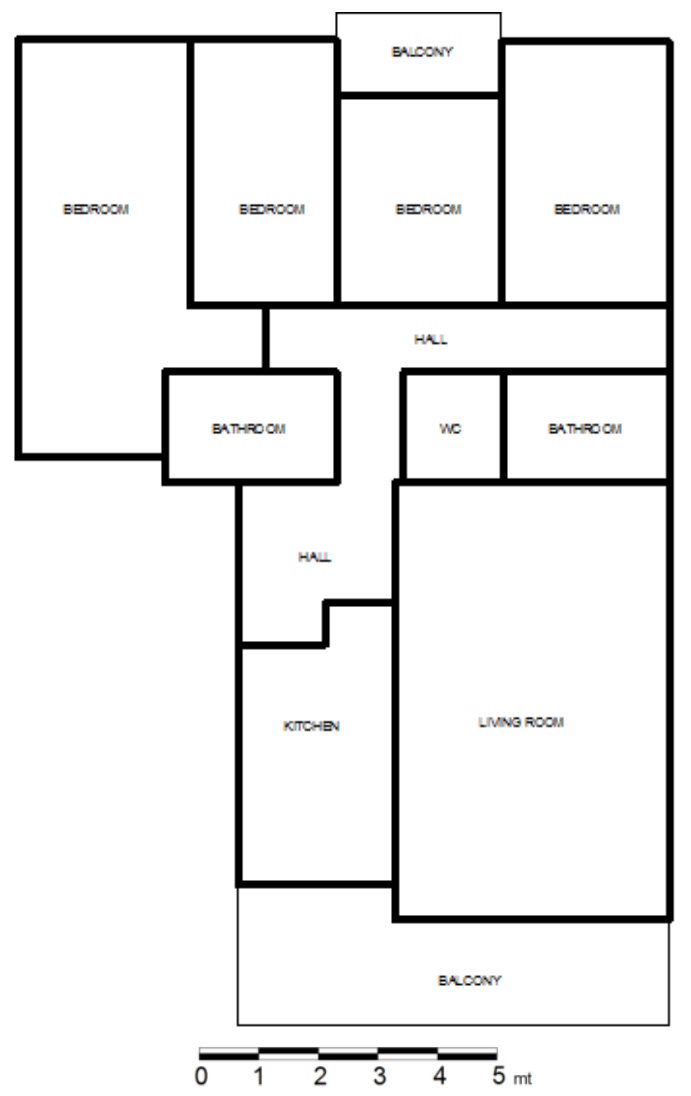

Fig. 15. The plan of a flat in Korupark in 2000s.

\section{CONCLUSION}

Residential buildings constructed since 1960s, which began to differ from traditional housing approach, until today where gated housing complexes emerge with diverse social and commercial centers, contributed to shape the urban character in Bursa. Since 1960s, streets were built wider and linear on the contrary to the existing organic structure. The plan schemes of the houses have changed in time. The traditional housing plan scheme was used for a while; however, the main hall that had access to all the rooms was replaced by a narrow corridor. It was common to have a second WC in the houses that were built in 1960's, while it was removed from the smaller apartments as the common bathroom fulfilled residents' needs in the following era. In 2000's the second WC was added again in the plan typology as a guest bathroom but this time European style closet was preferred instead of Turkish style toilet.

While saloon was only used when a guest would come by for a visit in religious holidays or special occasions, later this space started to be regularly used as a living room in daily life. Areas of the saloons that were used for dining and recreation purposes got larger and other rooms in the house were used as a bedroom for parents and children.

Narrow balconies, which were used only for hanging laundry out to dry or getting some fresh air or to add dynamism to the façade of the building in 1960s, started to be used as sitting areas with larger space in 2000's. Even after the transition from apartments to detached houses, the use of balconies continued with larger porches on the ground floor. In detached houses, the number of kitchens and saloons were increased to two as the area of usage got larger. The facilities such as Turkish bath and sauna were included in houses for high-income groups.

Although individuals' demand for space increased in time challenging construction industry to make a difference in housing character, the residential areas built in the last decades are composed of very similar buildings, which have only a couple diversity in details.

\section{REFERENCES}

[1] Ş. ÇOL, "Kentlerimizde Kimlik Sorunu ve Gunumuz Kentlerinin Kimlik Derecesini Olçmek İçin Bir Yontem Denemesi," (A Testing Method to Qualify the Rate of the Identity of Modern Day Cities and Identity Problem in Our Cities) Ph.D. dissertation, Dept. Arch., MSGSU, İstanbul, 1998.

[2] E. Kagıtçıbaşı and E. Yaşar, Bursa'nın Ekonomik Tarihi 1326-1900 (Economical History of Bursa 1326-1900), Bursa, ch. 1, pp. 31-35.

[3] A. Martal, "Degişim Surecinde İzmir'de Sanayileşme," (Industrialisation During the Period of Change in İzmir), Dokuz Eylul University Publications, 1999.

[4] T. Kaprol, "Cumhuriyet Sonrası 1930-1950 Yılları Arasında Bursa'da Mimari Gelișim," Architectural Improvement in Bursa Between 1930-1950 After Republic, Uludag University EngineeringArchitecture Faculty Periodicals, vol. 7, no. 1, 2002.

[5] H. Turkoglu, "Cumhuriyet Donemi'nde Bursa'nın Kentsel Gelişimi ve Planlamas1 (Urban Improvement and Planning of Bursa in Rebuplical Period)," Istanbul Technical University, Faculty of Architecture, Department of Urban and Regional Planning, İTU Mimarlık Fakultesi Şehir ve Bolge Planlama Bolumu, Ankara, 1997.

[6] D. Eyuboglu, "2000li Y1llarda Organize Sanayi Bolgelerimiz (Organized Industrial Zones by 2000s)," Verimlilik Periodicals, vol. 1, no. 3,2005 .

[7] T. Kaprol, “Cumhuriyet Sonrası 1930-1950 Yılları Arasında Bursa'da Mimari Gelișim(Architectural Improvement in Bursa Between 1930-1950 After Republic)," Uludag University EngineeringArchitecture Faculty Periodicals, vol. 7, no. 1, 2002.

[8] H. O. Tumer, "Dışa Kapalı Konut Yerleşmelerinin Bursa' daki Ornekler Kapsamında Degerlendirilmesi (Interpretation of the Gated Community Accomodatios within the Examples from Bursa)," M.S. thesis Uludag University, Bursa, 2006.

[9] Z. D. Abacı, "Modernleşme Surecinde Bursa Kenti’nin Mekansal ve Sosyal Degişimi (1860-1910) (The Conversion of Urban and Social State of Bursa in Modernisation Process)," Ph.D.dissertation Dept. Social Sciences, Uludag University, Bursa, 2005.

[10] E. Tosun and Z. Fırat, "Kentsel Mekanda Degişimler ve Kișilerin Konut Tercihi, Bursa Ornegi (Bursa as an Example of Conversion in Urban Space and Individual Preference of Houses)," Business and Economics Research Journal, vol. 3, no. 1, 2012.

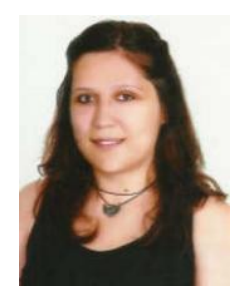

Saliha Tupal Yeke was born in Bursa in 1982 and she started architecture education in Istanbul Technical University in 2000 and graduated as an architect in 2004. She started to the master degree in Istanbul Technical University Department of Restoration University and completed in 2007. She continued to work with historical sites and buildings in İstanbul, Bursa. She started her doctorate in Uludag University Faculty of Architecture Department of History of Architecture and continues there. 


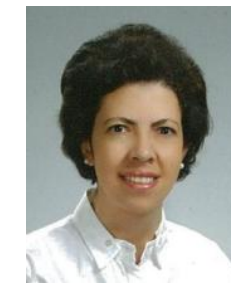

Selen Durak was born in Bursa and she was graduated from Middle East Technical University as a bachelor of architect in 1996. She completed her master degree of architecture in Uludag University Architecture Department in 2003 and $\mathrm{PhD}$ degree in Middle East Technical University in 2010. Now she is working as an associate professor in Uludag University Faculty of Architecture. Her field of interest is universal and architecture and cultural heritage.

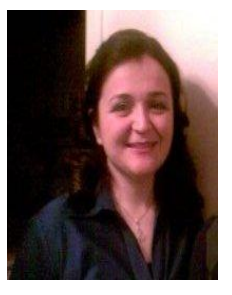

Tulin Vural Arslan was born in Bursa and she was graduated from Middle East Technical University as a bachelor of architect in 1996. She completed her master degree of architecture in Middle East Technical University in 1999 and $\mathrm{PhD}$ degree in Istanbul Technical University Faculty of Architecture in 2005. Now she is working as an associate professor in Uludag University Faculty of Architecture. Her field of interest is architectural design, design of shopping centers and the development and transformation of commercial districts in historic city centers. 